\title{
An experimental study to compare inflammatory response due to liquid or gas joint distension in horses submitted to arthroscopy ${ }^{1}$
}

\author{
Estudo experimental para comparar a resposta inflamatória decorrente da distensão líquida ou \\ gasosa em cavalos submetidos à artroscopia
}

\begin{abstract}
Renata Bello Rossetti ${ }^{\text {, Cristina de Oliveira Massoco }}{ }^{\mathrm{II}}$, Ana Carolina Alves Penna ${ }^{\mathrm{III}}$, Luis Claudio Lopes Correia da Silva ${ }^{\mathrm{IV}}$
IFellow PhD degree, Postgraduate Program in Surgery, Faculty of Veterinary Medicine, USP, Sao Paulo-SP, Brazil. Main author. Design and conception of the study, acquisition, interpretation and analysis of data.

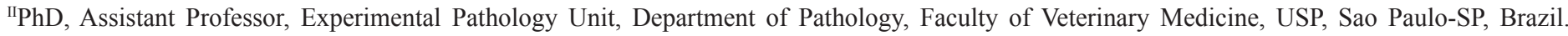
Supervised laboratory phases of the study, manuscript writing, critical revision.

IIIFellow Master degree, Postgraduate Program in Surgery, Faculty of Veterinary Medicine, USP, Sao Paulo-SP, Brazil. Involved in technical procedures. ${ }^{\mathrm{IV}} \mathrm{PhD}$, Associate Professor, Department of Surgery, Faculty of Veterinary Medicine, USP, Sao Paulo-SP, Brazil. Responsible for conception and design of the study, critical revision.
\end{abstract}

\section{ABSTRACT}

PURPOSE: To assess comparatively the inflammatory response that follows $\mathrm{CO}_{2}$ or Ringer's lactate joint capsular distension of horses submitted to experimental arthroscopy

METHODS: Each animal was submitted to a bilateral tarsocrural arthroscopy employing gas distention in one joint and fluid distention in the contralateral joint. Synovial fluid was evaluated at 0, six, 12, 24 and 48 hours post-operative.

RESULTS: The use of $\mathrm{CO}_{2}$ for arthroscopy causes an acute and mild synovitis alike to the liquid capsular distension, showing similar synovial fluid increase of leukocytes, TP, and TNF- $\alpha$. Although synovial fluid $\mathrm{PGE}_{2}$ content was higher in joints submitted to $\mathrm{CO}_{2}$ distension, lower levels of hemoglobin and leukocytes oxidative burst after surgery indicates that $\mathrm{CO}_{2}$ arthroscopy decreased intraarticular bleeding and activation of infiltrating leukocytes.

CONCLUSIONS: The use of $\mathrm{CO}_{2}$ for arthroscopic examination causes acute and mild synovitis that is similar to the effects caused by the liquid capsular distension. CO2 also seems to decrease intra-articular bleeding and activation of leukocytes.

Key words: Carbon Dioxide. Synovial Fluid. Joint Diseases. Synovitis. Flow Cytometry. Horses.

\section{RESUMO}

OBJETIVO: Avaliar comparativamente a resposta inflamatória decorrente da distensão líquida ou gasosa em cavalos submetidos ao exame artroscópico.

MÉTODOS: Cada animal foi submetido a uma artroscopia bilateral tarsocrural empregando uma distensão com gás em uma articulação e líquido na articulação contralateral. O líquido sinovial foi avaliado as zero, seis, 12, 24 e 48 horas do pós-operatório.

RESULTADOS: A utilização de $\mathrm{CO}_{2}$ para a artroscopia provoca uma sinovite aguda e leve tal como a distensão capsular por líquido, mostrando um aumento similar de leucócitos, TP (proteína total) e TNF- $\alpha$. Embora no líquido sinovial a quantidade de PGE 2 tenha sido maior nas articulações submetidas à distensão por $\mathrm{CO}_{2}$, níveis mais baixos de hemoglobina e explosão oxidativa de leucócitos após a cirurgia indica que a artroscopia com $\mathrm{CO}_{2}$ diminuiu o sangramento intra-articular e ativação de leucócitos.

CONCLUSÕES: A utilização de $\mathrm{CO}_{2}$ para exame artroscópico provoca uma sinovite aguda e leve que são semelhantes aos efeitos causados pela distensão capsular por líquido. $\mathrm{O} \mathrm{CO}_{2}$ também parece diminuir o sangramento intra-articular e a ativação de leucócitos. Descritores: Dióxido de Carbono. Líquido Sinovial. Artropatias. Sinovite. Citometria de Fluxo. Cavalos. 
An experimental study to compare inflammatory response due to liquid or gas joint distension in horses submitted to arthroscopy

\section{Introduction}

Although the use of carbon dioxide had been described since 1921 in the human literature ${ }^{1}$ liquid distension remains the most commonly protocol used in arthroscopy for joint capsule distension. Compared to fluid arthroscopy, the use of $\mathrm{CO}_{2}$ provides easier evaluation of intra-articular anatomical structures, increased joint space and visualization and also improves identification and removal of bone fragments ${ }^{2}$. Additionally, intra-articular bleeding does not cause the same amount of impaired vision as in liquid distension because blood will just follow gravity to the deepest point of the joint ${ }^{2}$.

Other advantages that gas distension using $\mathrm{CO}_{2}$ offers for operative arthroscopy is the possibility of using $\mathrm{CO}_{2}$ laser, microarthroscopy, in vivo staining of the synovial membrane and transplantation of chondrocytes and/or cancellous bone grafting ${ }^{2}$. Besides all this described advantages, the use of this technique remains controversial: catastrophic reports of fatal embolization ${ }^{2}$, increased pain ${ }^{3}$ and a tendency to cause some irritation to the joint in humans ${ }^{4}$ were described as complications of this technique.

The inflammatory response to arthroscopy using fluid capsular distension in horses was described as minimal, transient and frequently overwhelmed by its benefits to treatment ${ }^{5}$. However none of these effects has been investigated when employing $\mathrm{CO}_{2}$ during arthroscopic examination. Therefore, the aim of this study was to assess comparatively the inflammatory response that follows $\mathrm{CO}_{2}$ joint capsular distension to that of Ringer's lactate solution distension.

\section{Methods}

Nine health adult horses (weighing between 350 and $400 \mathrm{~kg}$ ) of mixed breed and sex, with no history or signs of tarsal joint diseases, normal findings on physical and lameness examination, tarsal radiographs, complete blood count, and synovial fluid analyses were studied. One tarsus of each horse was randomly assigned to gas distension (GD) and the opposite tarsus underwent the liquid distension (LD). During the experimental period the animals were kept in individual, 3 x 4 m stalls. Each animal was fed a total of $4 \mathrm{~kg}$ of pelleted concentrate, twice a day; while grass hay and water were offered ad libitum. Bedding consisted of wood shavings and was changed daily. The study protocol was approved by the Animal Care and Use Committee. All of the horses were cared for according to standards and guidelines and were adopted by private individuals upon conclusion of the study.

\section{Surgical procedure}

Horses were anesthetized, positioned in dorsal recumbency, and both hocks (tarsocrural joint) aseptically prepared for surgery. Synovial fluid samples were collected immediately before liquid distension of the joint for arthroscope insertion (M0). After distension of the tarsocrural joint with approximately $60 \mathrm{~mL}$ of Ringer's lactate solution, the arthroscope portal was made on the dorsal aspect of the dorsomedial pouch of the tarsocrural joint. A 19-gauge needle was inserted into the dorsolateral pouch and used to ensure a suitable location for the instrument portal. Joint distension was initially maintained by continuous irrigation with Ringer's lactate solution delivery by manual pressure until creation of the dorsolateral instrumental portal by stab incision. After this moment, in one joint (Group GD) warmed carbon dioxide $\left(\mathrm{CO}_{2}\right)$ was delivered by a laparoscopic insufflator and the gas pressure set at $24 \mathrm{mmHg}$. The joint was distended for 25 minutes and followed by lavage of the joint with ringer's solution for five minutes. At the contralateral limb (Group LD), the joint was distended by Ringer's lactate solution at a pressure of $24 \mathrm{mmHg}$ for 30 minutes after the instrument portal was created.

After the 30 minutes of distension, the excess liquid was drainage from both joints and skin portals were closed with nonabsorbable suture. Sterile bandages were applied.

\section{Postoperative care}

Horses received ceftiofur $(2.2 \mathrm{mg} / \mathrm{kg}$ intravenously) before induction of anesthesia and every 24 hours for two days. Because the aim of the study was to assess the inflammatory response, no NSAIDs were used after surgery but pain was successfully managed using the opioid petidine $(4 \mathrm{mg} / \mathrm{kg}$ intramuscularly) every 12 hours for two days.

\section{Synovial fluid sample collection and analysis}

Synovial fluid specimens were collected aseptically from the dorsomedial pouch of the tarsocrural joint at time 0 , six, 12, 24 and 48 hours after surgery in heparinized syringes. Synovial fluid color and clarity were evaluated subjectively immediately after collection, and total protein, hemoglobin and leukocytes concentrations were determined by use of routine clinicopathologic methods (biuret technique, photometric detection of cyanmetahemoglobin and manual count). As described previously ${ }^{6}$ color of synovial fluid was graded as yellow, orange or red, and numerical values of 1 to 3 , respectively, were assigned. 
Clarity was graded as clear, hazy, cloudy or opaque, and numeric values of 1 to 4 , respectively were assigned. Differential leukocyte counts were made by counting 100 cells on direct smears that were air dried and stained with Methanol-May Grunwald-Giemsa. Synovial fluid samples for analysis of total protein, hemoglobin and TNF- $\alpha$ were collected in microtubes and centrifuged, and the cell free supernatant was stored at $-80^{\circ} \mathrm{C}$ until assay.

\section{Quantification of leukocyte oxidative burst}

Quantification of oxidative burst was estimated using a flow cytometry by mean DCFH-DA fluorescence/cell as proposed by Hasui et al. ${ }^{7}$. Briefly, 2 x $10^{5}$ synovial cells in $100 \mathrm{~L}$ of PBS (Phosphate Buffered Saline) was mixed with DCFHDA (2',7'-dichlorfluorescein-diacetate) and incubated for 20 minutes at $37^{\circ} \mathrm{C}$. Erythrocytes were lysed and the cell pellets was ressuspended in $500 \mu \mathrm{L}$ of cold PBS for flow cytometry analysis. Direct measurement of mean fluorescence of green was recorded as oxidative burst. The flow cytometer (FACSCALIBUR, Benton Dickinson Immunocytometry Systems, San Jose, CA, USA) was utilized and data from 10000 events within the leukocytes gates were collected in a list mode and analyzed using the Cell Quest Pro software (Cell Quest Pro - Benton Dickinson, San Jose, CA, USA).

\section{Tumor necrosis factor- $\alpha$ bioassay}

The bioassay for TNF- $\alpha$ was adapted from the assay described by Santos et $\mathrm{al}^{8}{ }^{8}$ on the cytotoxic effect of TNF $\alpha$ on the murine fibroblast cell line L929. Briefly, a volume of $100 \mu \mathrm{L}$ of synovial fluid supernatant and $10 \mu \mathrm{L}$ of actinomicin D $(2 \mu \mathrm{g} / \mathrm{ml})$ was added to each well and plates incubated overnight. Cell growth/death was determined by adding $20 \mu \mathrm{L}$ MTT ([3-(4,5-dimethylthiazol-2-yl)-2,5-diphenyl tetrazolium bromide]), $(5 \mathrm{mg} / \mathrm{ml})$, incubating by $3-4 \mathrm{~h}$ at $37^{\circ} \mathrm{C}$, decanting of the medium and dissolving the color by adding $100 \mu \mathrm{L}$ of acidified isopropanol $(0,04 \mathrm{~N} \mathrm{HCL})$ per well. After $1 \mathrm{~h}$ the absorbance was then read at $590 \mathrm{~nm}$. TNF- $\alpha$ concentration was quantified in duplicate and a standard curve was produced using recombinant human TNF-_ $\alpha$ because purified equine cytokines were not available. Therefore, estimated concentrations of equine TNF-_ $\alpha$ were expressed in $\mathrm{pg} / \mathrm{ml}$.

\section{Quantification of $P G E_{2}$}

The $\mathrm{PGE}_{2}$ concentration was determined by use of commercially available human PGE 2 EIA Kits (Cayman, EUA) according manufacturer's instructions.

\footnotetext{
${ }^{a}$ GraphPad Instat, GraphPad Software, San Diego, CA, USA.
}

\section{Statistical analysis}

Statistical analyses were performed using computer software $^{1}$. For synovial fluid total protein, hemoglobin concentrations and leucocytes count, Kruskal-Wallis nonparametric tests followed by Dunn post test was used to evaluate differences between distension protocols and among different times of collection. Pairwise comparisons were made at each time point for synovial fluid $\mathrm{PGE}_{2}, \mathrm{TNF}-\alpha$ and oxidative burst production, using Friedman two-way analysis of variance by ranks. Results are expressed as means \pm SEMs. Synovial fluid $\mathrm{PGE}_{2}$ concentration was expressed as a ratio, compared with values for baselines samples. A paired $t$ test was used to evaluate differences between distension protocols. A significance level of $p \leq 0.05$ was assigned for all tests.

\section{Results}

\section{Color and clarity of synovial fluid}

After six hours (M6), all specimens were similarly cloudy and red in color. Although all samples remained cloudy in every moment, after M6, the liquid from joints of group GD started to became orange in color differentially from group LD where all samples remained red until M48.

\section{Synovial fluid WBC count}

Significant differences were not detected in relation to number of cell between groups but in the kinetic cell migration group GD it was observed a more acute increase in WBC count compared to it control values at M6 and M12 ( $<<0.01$ to M0). The group LD only reached its peak at M12 ( $<<0.01$ compared to M0). After M12, the WBC count decreased similarly in both groups but remained significant higher than M0 values at M48 $(\mathrm{p}<0.05)$ (Figure 1).

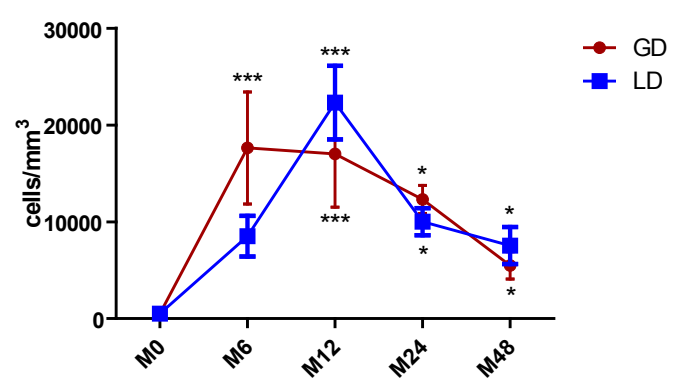

FIGURE 1 - WBC count observed at $0,6,12,24$ and 48 hours after arthroscopy. Significant differences marked for $* \mathrm{p}<0.05$ and $* * * \mathrm{p}<0.01$ versus $\mathrm{M} 0$. 


\section{Differential WBC counts of synovial fluid}

All specimens collected before the surgical procedure were in normal values (ie, few cells, mostly mononuclear). At M6, M12, M24 and M48, the predominant cell type was a nondegenerate neutrophil, reaching it higher percentage in both groups at M6, M12, M24 and M48 ( $<<0.05$ compared to M0). Only at group GD a tendency to return to normality was noted by an increase in the presence of mononuclear cells because at M48 the percentage of mononuclear cells was significant higher $(\mathrm{p}<0.01)$ than it percentage at M6 (Table 1).

TABLE 1 - Percentage of differential count of synovial fluid cells from horses collected before and after liquid or gas capsular distension during experimental arthroscopy (means \pm SEMs). M0, M6, M12, M24 and M48= before and at 6, 12, 24 and 48 hours after arthroscopy, respectively. GD= Gas distension; $\mathrm{LD}=$ liquid distension.

\begin{tabular}{ccccc}
\hline $\begin{array}{c}\text { Time of } \\
\text { collect }\end{array}$ & $\begin{array}{c}\text { GD } \\
\text { PMN }\end{array}$ & $\begin{array}{c}\text { GD } \\
\text { MN }\end{array}$ & $\begin{array}{c}\text { LD } \\
\text { PMN }\end{array}$ & $\begin{array}{c}\text { LD } \\
\text { MN }\end{array}$ \\
\hline M0 & $4 \pm 0.5$ & $96 \pm 0.14$ & $2 \pm 0.1$ & $98 \pm 0.35$ \\
M6 & $93 \pm 0.25^{*}$ & $6.5 \pm 0.30^{*}$ & $86,5 \pm 1^{*}$ & $13 \pm 0.8^{*}$ \\
M12 & $90 \pm 0.8^{*}$ & $9 \pm 1.5^{*}$ & $87 \pm 1.5^{*}$ & $11 \pm 0.35^{*}$ \\
M24 & $78 \pm 0.4^{*}$ & $21 \pm 0.9^{*}$ & $77 \pm 1^{*}$ & $16 \pm 2.5^{*}$ \\
M48 & $65 \pm 1.2^{*}$ & $34 \pm 1.5^{* *}$ & $62 \pm 0.8^{*}$ & $37 \pm 0.5^{*}$ \\
\hline
\end{tabular}

${ }^{*} \mathrm{p}<0.05$ compared to $\mathrm{M} 0 ;{ }^{* *} \mathrm{p}<0.01$ compared to M0

Total protein and hemoglobin concentration of synovial

fluid

A similar change in total protein concentration was observed in both groups. The two groups had long lasting increase in total protein levels that reached its peak 24 hours after the surgical procedure. Although no statistical significant difference was noted between groups regarding its hemoglobin concentration, the pattern of change over time was dramatically different. Both groups presented a similar increase at M6 although only LD group presented a significant difference $(\mathrm{p}<0.01$ compared to $\mathrm{M} 0)$. After this moment the specimens from group DG demonstrated a decrease and stabilization until M48. Meanwhile, joints submitted to liquid distension showed an increase in concentration reaching its peak at M24 $(\mathrm{p}<0.001$ compared to M0) and remained significant higher than it control levels at M48 $(\mathrm{p}<0.05)$ (Table 2).
TABLE 2 - Concentration of hemoglobin (g/dL) from tarsocrural joints from horses before and after liquid or gas capsular distension during experimental arthroscopy (means \pm SEMs). M0, M6, M12, M24 and M48= before and at 6, 12, 24 and 48 hours after arthroscopy, respectively. GD= Gas distension; $\mathrm{LD}=$ liquid distension.

\begin{tabular}{ccc}
\hline Time of collect & $\begin{array}{c}\text { GD } \\
(\mathbf{g} / \mathbf{d L})\end{array}$ & $\begin{array}{c}\text { LD } \\
(\mathbf{g} / \mathbf{d L})\end{array}$ \\
\hline M0 & $0.001 \pm 0.001$ & $0,004 \pm 0.02$ \\
M6 & $0.03 \pm 0.006$ & $0.042 \pm 0.01^{*}$ \\
M12 & $0.02 \pm 0.8$ & $0.04 \pm 1.5^{*}$ \\
M24 & $0.035 \pm 0.02$ & $0.082 \pm 0.04^{* *}$ \\
M48 & $0.031 \pm 0.03$ & $0.05 \pm 0.02 * *$ \\
\hline
\end{tabular}

$* \mathrm{p}<0.05$ compared to $\mathrm{M} 0 ; * * \mathrm{p}<0.01$ compared to M0

\section{Quantification of leukocyte oxidative burst}

Figure 2 (A and B) shown synovial cells identified by typical cytogram side scatter (SSC) versus forward scatter (FSC) cytogram of equine synovial fluid before and after arthroscopy. This figure is representative of equine synovial cellular and revealed mononuclear (MNC) (synoviocytes, monocytes and macrophages) and polymorphonuclear cell population (PMN) (neutrophil) that was gated according to their granularity and size thus excluding debris cellular of analysis. Based on this cytogram we could set histograms where the more green fluorescence a cell emits (corresponding to more ROS), the farther to the right the cell data will appear on the histogram.
A

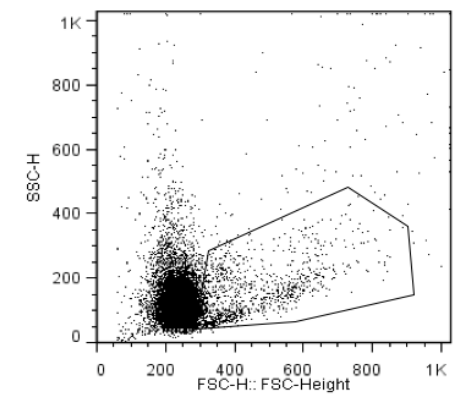

B

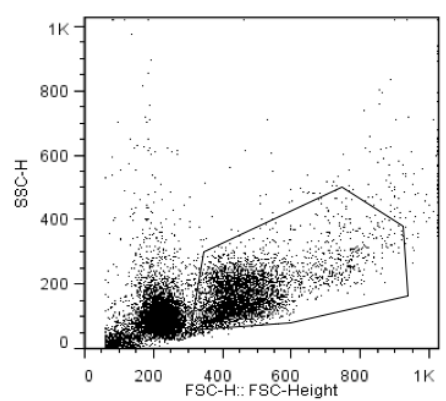

FIGURE 2 - Cytogram representative of synovial cells by flow cytometry. A. Before arthroscopy; B. After arthroscopy. 
Figure 3 shows a measurement of green mean fluorescence which is representative of oxidative burst of DCFH-loaded PMN cells. The oxidative burst of PMN demonstrated a significant increase in activity at M6, M24 and M48 in the samples from group LD and GD. The samples from group GD demonstrated a decrease on its burst activity while the samples from group LD remained significantly active when compared to it control values $(\mathrm{p}<0.05)$.

At the joints submitted to gas distension, the oxidative burst by PMN increased four fold to it control levels after the surgical procedure and remained significantly high until M48 ( $p<0.05$ to control levels).

The oxidative burst by macrophages increased after the surgical procedure in both groups.

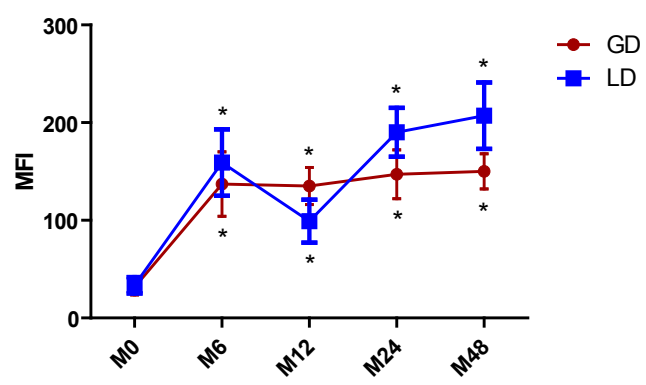

FIGURE 3 - Oxidative burst of PMN cells from synovial fluid observed at $0,6,12,24$ and 48 hours after arthroscopy. Gate analysis was set on PMN cells using forward and side scatter gating. Values represent mean fluorescence intensity (MFI) in gated cells. Data are represented as mean $\pm \mathrm{SD} .{ }^{*} \mathrm{p}<0.05$ in comparison to M0.

\section{$P G E_{2}$ production}

Synovial fluid $\mathrm{PGE}_{2}$ ratio was significantly increased over time in joints of both groups (Figure 4) compared with M0. Although no statistically different, the joints submitted at gas distension had peak ratio of $11 \pm 3$ times of the control levels versus $5.1 \pm 1$ times greater than the control levels from the joints from LD. These peak ratios were observed at 12 hours (M12). Gas distension also had a significant decrease to its peak values $(\mathrm{p}<0.05)$ when compared to 12 hours after the surgical procedure.

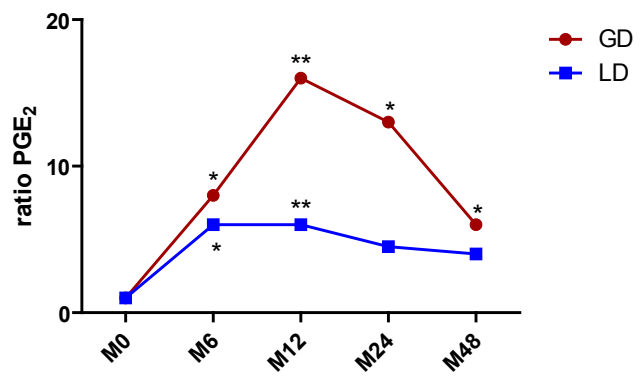

FIGURE 4 - PGE ratio from synovial fluid observed at 0, 6, 12, 24 and 48 hours after arthroscopy. ${ }^{*} \mathrm{p}<0.05$ and ${ }^{* *} \mathrm{p}<0.01$ in comparison to M0 and M12.

\section{TNF- $\alpha$ production}

TNF- $\alpha$ concentration was increased two folds at six hours after the surgical procedure in both groups in a similar way but not statistically significant compared to its baseline values. At 12 hours both groups TNF- $\alpha$ concentration had already returned to control values (Figure 5).

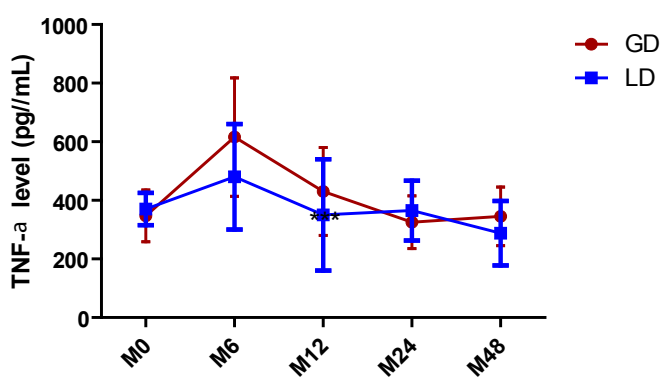

FIGURE 5 - Synovial fluid TNF level observed at 0, 6, 12, 24 and 48 hours after arthroscopy.

\section{Discussion}

Gas and liquid capsular distension provoked an acute synovitis with minimal clinical manifestation after surgery and both distension protocols induced a rapid cellular inflammatory response identified by significant synovial fluid leukocytosis, increased oxidative burst production and increased release of the mediators TNF- $\alpha$ and $\mathrm{PGE}_{2}$ at six hours after the surgical procedure.

The magnitude of increase in synovial fluid white blood cells (WBC) and the neutrophilic response were comparable to those observed by Bertone et al. ${ }^{9}$ when testing different types of lavage solutions. Bertone et al..$^{9}$ believe that variations at intraarticular $\mathrm{pH}$ can cause a significant transient elevation in synovial fluid WBC.

Carbon dioxide dissolves in water $\left(\mathrm{H}_{2} \mathrm{O}\right)$ to form $\mathrm{H}_{2} \mathrm{CO}_{3}$, which is an acid and can decrease intra-articular $\mathrm{pH}$. This acidic environment could be the cause of the more acute influx of WBC observed in the joints submitted to gas distension. Although the inflammatory stimulus could be higher when using $\mathrm{CO}_{2}$, this stimulus is short-lived because $\mathrm{CO}_{2}$ is rapidly absorbed to the blood stream. Small lipophilic solutes such as $\mathrm{O}_{2}$ and $\mathrm{CO}_{2}$ are easily exchanged between synovial fluid and plasma by the synovial capillares, while lymphatics slowly remove macromolecules and fluid $^{10}$.

The occurrence of change in color and clarity of synovial fluid samples after joint lavage or arthroscopy had already been described by others ${ }^{9,11}$ and are similar to those changes observed in 
An experimental study to compare inflammatory response due to liquid or gas joint distension in horses submitted to arthroscopy

our study. Jones et al. ${ }^{11}$ observed turbid and slightly hemorrhagic samples for four weeks after arthroscopy using lactated Ringer's solution. Samples from GD group also had smaller concentration of $\mathrm{Hb}$ after $\mathrm{M} 6$ than the samples from $\mathrm{LD}$, indicating lower hemolysis and red cells influx. The occurrence of higher levels of $\mathrm{Hb}$ and more red-colored color in synovial samples of joint submitted to liquid distension indicates more bleeding in these joints. The use of gas distension not only avoid the occurrence of the so-called red-out effect by intra-articular hemorrhage ${ }^{2}$ but also decrease bleeding deriving from the surgical procedure.

The presence of a higher concentration of $\mathrm{Hb}$ in the joints submitted to liquid distension can be deleterious to the joint in long-term. Tajima et al. ${ }^{12}$ suggest a possible role of $\mathrm{Hb}$ in joint damage after intra-articular bleeding by articular cartilage degradation and release of cartilage matrix components into the synovial fluid.

The concentration of molecules in the synovial fluid is used as a measure of synovial membrane inflammation because the concentration is determined by passage of molecules through endothelial walls, diffusion between synoviocytes intercellular spaces, and production by synovial lining cells ${ }^{13}$. For both distension protocols, protein concentration increased slowly compared to other inflammatory mediators because reached its peak only 12 hours after the procedure and remained in higher concentrations until 48 hours after the procedure.

Our results regarding the oxidative burst demonstrate that significantly higher oxidative burst observed in this experiment by the joints of group LD suggests that the joint distension protocol using Ringer lactate's can potentially cause a bigger oxidative damage to joint when compared to gas distension. Apparently the joints submitted to $\mathrm{CO}_{2}$ distension suffered a higher inflammatory stimulus to the synovial membrane compared to the joints submitted to liquid distension, because PGE is considered one of the principals' indicators of active synovial inflammation ${ }^{14}$ and this joints also had a higher and more acute increase in the WBC.

The peak of TNF probably preceded our first sampling after surgery at six hours because at this moment we verified the maximum level of TNF in both groups but were not significant higher than baseline values. The maximum levels of TNF in joint fluid preceded the infiltration of leukocytes and coincide with the data reported by Pettipher and Salter ${ }^{15}$ that TNF is produced from the resident joint tissues such as the synovial lining cells rather than infiltrating neutrophils or monocytes. Apparently the TNF values at our study were not influenced by repeated arthrocentesis similarly as reported by Cornelissen et al. ${ }^{16}$.

\section{Conclusion}

The use of $\mathrm{CO}_{2}$ for arthroscopy examination in horses induces transient synovitis similar to the one observed after Ringer's lactate solution and is safe to be used in horses.

\section{References}

1. Bircher E. Die Arthroendoskopie. Zentralbl Chir. 1921;48:1460-1.

2. Eriksson E, Sebik A. Arthroscopy and arthroscopic surgery in a gas versus a fluid medium. Orthop Clin North Am. 1982;13:293-8.

3. Ridell RR. CO2 arthroscopy of the knee. Clin Orthop Relat Res. 1990;25:92-4.

4. Garrick JG, Kadel N. The CO2 laser in arthroscopy: potential problems and solutions. Arthroscopy. 1991;7:129-37.

5. Jacobsen S, Nielsen JV, Kjelgaard-Hansen M, Toelboell T, Fjeldborg J, Halling-Thomsen M, Martinussen T, Thoefner MB. Acute phase response to surgery of varying intensity in horses: a preliminary study. Vet Surg. 2009;38:762-9.

6. Frisbie DD, Kawcak CE, Baxter GM, Trotter GW, Powers BE, Lassen ED, Mcilwraith CW. Effects of $6 \alpha$-methylprednisolone acetate on equine osteochondral fragment exercise model. Am J Vet Res. 1998;59:1619-28.

7. Hasui M, Hirabayashi Y, Kobayashi, Y. Simultaneous measurement by flow cytometry of phagocytosis and hydrogen peroxide production of neutrophils in whole blood. J Immunol Methods. 1989;117:53-8.

8. Santos BC, Starobinas N, Barbuto JAM, Russo M, Schor N. Absence of peripheral blood mononuclear cells priming in hemodialysis patients. Braz J Med Biol Res. 2003;36:219-25.

9. Bertone AL, Mcilwraith CW, Powers BE, Radin MJ. Effect of four antimicrobial lavage solutions on the tarsocrural joint of horses. Vet Surg. 1986;15:305-15

10. Ahlqvist J. Swelling of synovial joints -An anatomical, physiological and energy metabolical approach. Pathophysiology. 2000;7:1-19.

11. Jones DL, Barber SM, Doige CE. Synovial fluid and clinical changes after arthroscopic partial synovectomy of the equine middle carpal joints. Vet Surg. 1993;22:524-30.

12. Tajima T, Yoshida E, Yamashita A, Ohmura S, Tomitaka Y, Sugiki M, Asada Y, Maruyama M. Hemoglobin stimulates the expression of matrix mateloproteinases, MMP-2 and MMP-9 by synovial cells: a possible cause of joint damage after intra-articular hemorrhage. J Orthop Res. 2005;5:891-8.

13. Wallis WJ, Simkin PA. Protein traffic in human synovial effusions. Arthritis Rheum. 1987;30:57-63.

14. Kirker-Head CA, Chandna VK, Agarwal RK, Morris EA, Tidwell A, O'Callaghan MW, Rand W, Kumar MS. Concentrations of substance $\mathrm{P}$ and prostaglandin $\mathrm{E} 2$ in synovial fluid of normal and abnormal joints of horses. Am J Vet Res. 2000;6:714-8.

15. Pettipher ER, Salter ED. Resident joint tissues, rather than infiltrating neutrophils and monocytes, are the predominant sources of TNF- $\alpha$ in zymosan-induced arthritis. Cytokine. 1996;8:130-3.

16. Cornelissen BP, Rijkenhuizen AB, van den Hoogen BM, Rutten VP, Barneveld A. Experimental model of synovitis/capsulitis in the equine metacarpophalangeal joint. Am J Vet Res. 1998;59:978-85 
Rossetti RB et al.

\section{Correspondence:}

Cristina de Oliveira Massoco

Av. Prof. Dr. Orlando Marques de Paiva, 87

Departamento de Patologia-FMVZ-USP

05508-900 São Paulo - SP Brasil

Tel.: (55 11)3091-1376

cmassoco@usp.br

Received: July 10, 2012

Review: September 11, 2012

Accepted: October 15, 2012

Conflict of interest: none.

Financial source: FAPESP (Sao Paulo Research Foundation - 04/14930-0)

${ }^{1}$ Research performed at Laboratory of Pharmacology, Department of Pathology and Animal Hospital, Faculty of Veterinary Medicine, University of Sao Paulo (USP), Brazil. Part of Fellow Master degree thesis, Postgraduate Program in Surgery. Tutor: Prof. Dr. Luis Claudio Lopes Correia da Silva. 